\title{
A new method for the determination of L-DOPA and 3-O- methyldopa in plasma and cerebrospinal fluid using gas chromatography and electron capture negative ion mass spectrometry
}

\section{Citation for published version (APA):}

Jong, de, A. P. J. M., Kok, R. M., Cramers, C. A. M. G., Wadman, S. K., \& Haan, de, E. (1988). A new method for the determination of L-DOPA and 3-O-methyldopa in plasma and cerebrospinal fluid using gas chromatography and electron capture negative ion mass spectrometry. Clinica Chimica Acta, 171(1), 49-61. https://doi.org/10.1016/0009-8981(88)90290-2

DOI:

10.1016/0009-8981(88)90290-2

Document status and date:

Published: 01/01/1988

\section{Document Version:}

Publisher's PDF, also known as Version of Record (includes final page, issue and volume numbers)

\section{Please check the document version of this publication:}

- A submitted manuscript is the version of the article upon submission and before peer-review. There can be important differences between the submitted version and the official published version of record. People interested in the research are advised to contact the author for the final version of the publication, or visit the $\mathrm{DOI}$ to the publisher's website.

- The final author version and the galley proof are versions of the publication after peer review.

- The final published version features the final layout of the paper including the volume, issue and page numbers.

Link to publication

\footnotetext{
General rights

- You may freely distribute the URL identifying the publication in the public portal. follow below link for the End User Agreement:

www.tue.nl/taverne

\author{
Take down policy \\ If you believe that this document breaches copyright please contact us at: \\ openaccess@tue.nl \\ providing details and we will investigate your claim.
}

Copyright and moral rights for the publications made accessible in the public portal are retained by the authors and/or other copyright owners and it is a condition of accessing publications that users recognise and abide by the legal requirements associated with these rights.

- Users may download and print one copy of any publication from the public portal for the purpose of private study or research.

- You may not further distribute the material or use it for any profit-making activity or commercial gain

If the publication is distributed under the terms of Article 25fa of the Dutch Copyright Act, indicated by the "Taverne" license above, please 


\title{
A new method for the determination of L-DOPA and 3-O-methyldopa in plasma and cerebrospinal fluid using gas chromatography and electron capture negative ion mass spectrometry
}

\author{
A.P.J.M. de Jong ${ }^{\text {a }}$, R.M. Kok ${ }^{a}$, C.A. Cramers ${ }^{\text {b }}$, S.K. Wadman ${ }^{c}$ \\ and E. Haan ${ }^{\mathrm{d}}$ \\ ${ }^{a}$ Department of Pediatrics, Free University Hospital, Amsterdam, ${ }^{b}$ Department of Instrumental Analysis, \\ Eindhoven University of Technology, Eindhoven and ' University Children's Hospital, \\ Het Wilhelmina Kinderziekenhuis, Utrecht (The Netherlands) \\ and ${ }^{d}$ The Adelaide Children's Hospital, North Adelaide (Australia)
}

(Received 5 December 1986; revision received 24 July 1987; accepted after revision 12 August 1987)

Key words: DOPA: 3-O-Methyldopa; Plasma; Cerebrospinal fluid; Gas chromatography-electron capture negative ion mass spectrometry; Normal values; Kinetics

\section{Summary}

L-3-(3,4-Dihydroxyphenyl)alanine (DOPA) and its 3- $O$-methyl metabolite (OMD) were measured in plasma and cerebrospinal fluid by a new assay which combines $\mathrm{N}, \mathrm{O}$-acetylation of amino acids in aqueous media, preparation of pentafluorobenzyl esters under anhydrous conditions, and analysis by gas chromatography-electron capture negative ion mass spectrometry. The $N, O$-acetyl, carboxy-PFB derivatives gave abundant carboxylate anions $\left(\left[\mathrm{M}-\mathrm{CH}_{2} \mathrm{C}_{6} \mathrm{~F}_{5}\right]^{-}\right)$which were suitable for sensitive analysis using selected ion monitoring. Plasma and CSF samples were sufficiently purified by a simple organic solvent extraction. Analytical recovery for DOPA was $100.2 \pm 3.7 \%$ at the level of $100 \mathrm{nmol} / 1$. Analysis of DOPA in plasma was performed with a relative standard deviation of $5 \%$. The limit of quantitation in plasma and CSF was at the sub-nmol/l level. In healthy adults, DOPA concentration in plasma was $9.0 \pm 2 \mathrm{nmol} / \mathrm{l}(n=11)$ and in CSF $3.5 \pm 0.9 \mathrm{nmol} / 1(n=9)$. The concentration of OMD in plasma was $99.1 \mathrm{nmol} / \mathrm{l}$ (pool of 24 samples) and $15.3 \mathrm{nmol} / \mathrm{l}$ in CSF (pool of 12 samples). Measurement of $5-\left[{ }^{2} \mathrm{H}\right] \mathrm{DOPA}$ and $5-\left[{ }^{2} \mathrm{H}\right] \mathrm{OMD}$ in plasma of a healthy individual who had been orally loaded with $3,5-\left[{ }^{2} \mathrm{H}_{2}\right]$ tyrosine ( $150 \mathrm{mg} \mathrm{kg}$ body wt) was possible for several hours after the load.

Correspondence to (present address): A.P.J.M. de Jong, Laboratory for Organic Analytical Chemistry, National Institute for Public Health and Environmental Hygiene, P.O.B 1, 3720 Bilthoven. The Netherlands. 


\section{Introduction}

L-3(3,4-Dihydroxyphenyl)alanine (DOPA), the natural precursor of catecholamines and melanins, is formed by hydroxylation of tyrosine (Tyr). In the catecholamine pathway this conversion is catalyzed by tyrosine hydroxylase (EC 1.14.16.2) and by tyrosinase (EC 1.14.18.1) in melanin synthesis. The conversion of Tyr into DOPA is thought to be the rate-limiting step in catecholamine synthesis [1]. Balanced rates of formation and metabolic removal of DOPA cause low steady-state levels in plasma. In normal urine only small amounts of DOPA have been found because $>99 \%$ of manufactured DOPA is metabolized before excretion [2]. At present, two techniques are known for their assessment in plasma, one using high performance liquid chromatography (HPLC) with electrochemical detection [3] and one using a radioenzymatic technique [4]. To date, gas chromatography-mass spectrometry (GC-MS) has not been utilized. However, this technique will be of value for the assay of minor amino acids in body fluids or tissue, and is inevitable for the in vivo study on the kinetics of formation and metabolism of DOPA using stable isotape labelled tyrosine or DOPA. Regarding the low endogenous level of DOPA in plasma, measurements of traces of in vivo produced labelled DOPA needs a highly sensitive mass spectrometric method. Electron capture negative ion (ECNI) chemical ionization has shown to provide improved sensitivity for compounds with electron affinity [5]. It was shown that pentafluorobenzyl (PFB) ester derivatives of endogenous acidic compounds exploit the potential sensitivity of the ECNI technique [6-8].

In a critical review, Labadarios et al [9] have shown that many problems will arise with present methods for deproteinization and clean-up of plasma samples and the subsequent preparation of volatile amino acid derivatives. In the present investigation we adopted the approach of derivatization of amino acids in the aqueous sample, first described by Ahnfelt and Hartvig [10]. By this approach amino acids were reacted at the amino group and, if present, at the phenolic hydroxy groups [11-13]. Their amphoteric and catecholic nature have been modified by this treatment and the stable derivatives can easily be recovered during organic solvent extraction. In addition, an advantage of this method is that amino and phenol groups have been protected during the formation of PFB esters. In this paper we describe a reliable method for the GCMS analysis of DOPA and OMD in plasma and cerebrospinal fluid (CSF). Normal values for these constituents are presented. In addition, the utility of the method is demonstrated by the measurement of $5-\left[{ }^{2} \mathrm{H}\right] \mathrm{DOPA}$ and $5-\left[{ }^{2} \mathrm{H}\right] \mathrm{OMD}$ in plasma following the administration of $3,5-\left[{ }^{2} \mathbf{H}_{2}\right]$ Tyr to a healthy individual.

\section{Experimental}

\section{Materials}

L-Tyrosine (Tyr), DOPA and L-3(4-hydroxy-3-methoxyphenyl)alanine (OMD) were obtained from Jansen Pharmaceutica (Beerse, Belgium). Methyl chloroformate and acetic anhydride (AA) were available from Merck (Darmstadt, FRG). Pentaflu- 
orobenzyl bromide (PFB-Br) was from Pierce Chemical Co. (Rockford, IL, USA). All solvents used were of analytical grade and were obtained from Merck. Ring deuterated isomers of Tyr $\left(3,5-\left[{ }^{2} \mathrm{H}_{2}\right] \mathrm{Tyr}\right)$; DOPA $\left(3,5,6-\left[{ }^{2} \mathrm{H}_{3}\right]\right.$ DOPA $)$ and OMD $\left(3,5,6-\left[{ }^{2} \mathrm{H}_{3}\right] \mathrm{OMD}\right)$ were synthesized according to Muskiet et al [14]. The phosphate buffer used was a $3 \mathrm{~mol} / 1 \mathrm{~K}_{2} \mathrm{HPO}_{4}$ solution in distilled water; the $\mathrm{pH}$ being adjusted to a value of 8.5 with concentrated phosphoric acid.

\section{Samples}

Blood samples $(5-10 \mathrm{ml})$ obtained by venipuncture were collected in tubes containing heparin as anticoagulant. The tubes were immediately placed on ice. Plasma was separated by centrifugation at $1000 \times \mathrm{g}$ for $10 \mathrm{~min}$ at $4^{\circ} \mathrm{C}$ and was then carefully transferred into polypropylene tubes containing $1 \mathrm{mg}$ of reduced glutathione and $1 \mathrm{mg}$ of ethylenediaminetetraacetic acid disodium salt (EDTA)/ml of plasma. The samples were stored at $-25^{\circ} \mathrm{C}$ until analysis.

CSF samples were on receipt at the laboratory immediately transferred into polypropylene tubes containing $1 \mathrm{mg}$ of reduced glutathione and $1 \mathrm{mg}$ of EDTA/ml of CSF, and stored at $-25^{\circ} \mathrm{C}$ until analysis.

\section{Sample preparation}

Plasma and CSF samples $(1 \mathrm{ml})$ were acidified with $2 \mathrm{ml}$ of hydrochloric acid $(100 \mathrm{mmol} / \mathrm{l})$ and saturated with sodium chloride. Deuterated $\left(3,5,6-\left[{ }^{2} \mathrm{H}_{3}\right]-\right)$ analogues of DOPA and OMD (2.5 and $10 \mathrm{ng}$, respectively) were added as internal standards. The mixture was extracted 4 times with $4 \mathrm{ml}$ of ethyl acetate by vigorous mixing for $5 \mathrm{~min}$. During extraction deproteinization of proteins occurred which caused a stable emulsion. This emulsion was usually broken by centrifugation at $2400 \times g$ for $5 \mathrm{~min}$. In case of failure, the emulsion was stirred with a glass rod and the tube was re-centrifuged $(2400 \times g$ for $15 \mathrm{~min})$. The clear supernatant (organic layer) was discarded each time. Finally, a portion $(2 \mathrm{ml})$ of the aqueous layer was transferred to a clean test-tube using a disposable pipette which was passed through the layer containing the proteins. This portion was subjected to the derivatization method.

\section{Derivatization}

Acetylation in aqueous medium The devised procedure has been standardized to handle samples containing the amino acids in $2 \mathrm{ml}$ of about $0.1 \mathrm{~mol} / 1$ hydrochloric acid. Smaller volume samples (aliquots of standard solutions) were adjusted to $2 \mathrm{ml}$ with $0.1 \mathrm{~mol} / \mathrm{l}$ hydrochloric acid. Then, $2 \mathrm{ml}$ of the phosphate buffer and $30 \mu \mathrm{l}$ of acetic anhydride were added in that order, and immediately mixed for about $10 \mathrm{~s}$. The reaction was allowed to proceed at room temperature for $5 \mathrm{~min}$. Then the mixture was acidified to $\mathrm{pH} 3$ by addition of $0.8 \mathrm{ml}$ of $6 \mathrm{~mol} / 1$ hydrochloric acid. The acetyl derivatives formed were extracted with $5 \mathrm{ml}$ of ethyl acetate by vigorous shaking for $5 \mathrm{~min}$. Phase separation was facilitated by centrifugation $(2400 \times g, 5$ min). A portion $(4 \mathrm{ml})$ of the organic layer was evaporated at $60^{\circ} \mathrm{C}$ with a stream of nitrogen. 
Preparation of pentafluorobenzyl esters The residue obtained after acetylation (above) was treated with a mixture of PFB-Br $(5 \mu 1)$, triethylamine $(10 \mu 1)$ and acetonitrile $(50 \mu 1)$ for $5 \mathrm{~min}$ at room temperature. Isolation of the PFB esters was performed by adding ethyl acetate $(3 \mathrm{ml})$ and $0.1 \mathrm{~mol} / 1$ hydrochloric acid $(1 \mathrm{ml})$. After mixing $(10 \mathrm{~s})$ and centrifugation $(2400 \times g, 5 \mathrm{~min})$ the organic layer $(2.5 \mathrm{ml})$ was transferred to a polypropylene test-tube and evaporated at $60^{\circ} \mathrm{C}$ with a stream of nitrogen. The residue was dissolved in $50 \mu \mathrm{l}$ of ethyl acetate for analysis by GCMS.

Gas chromatography-mass spectrometry

GCMS experiments were carried out on a Kratos MS-80 instrument (Kratos Ltd.. Manchester, UK). The resolving power was set at $R=1000$ (10\% valley). The mass spectrometric conditions for electron capture negative ion chemical ionisation were: moderating gas, ammonia; source temperature, $250^{\circ} \mathrm{C}$; electron energy was optimized for maximum sensitivity, normally between $50-80 \mathrm{eV}$; filament emission current: $1.5 \mathrm{~mA}$. Mass spectra were recorded at a scan speed of $1 \mathrm{~s}$ per decade. Selected ion recordings were performed at $-m / z-264$ and 266 for Tyr and $\left[{ }^{2} \mathrm{H}_{2}\right] \mathrm{Tyr} ; 294,295$ and 297 for OMD, $\left[{ }^{2} \mathrm{H}\right] \mathrm{OMD}$ and $\left[{ }^{2} \mathrm{H}_{3}\right] \mathrm{OMD}$; and 322,323 and 325 for DOPA, $\left[{ }^{2} \mathrm{H}\right]$ DOPA and $\left[{ }^{2} \mathrm{H}_{3}\right]$ DOPA, respectively. The dwell-time was $50 \mathrm{~ms}$ per channel. The chromatographic column was a $25 \mathrm{~m} \times 0.22 \mathrm{~mm}$ i.d. fused silica capillary column coated with chemically bounded OV-17, film thickness 0.12 $\mu \mathrm{m}$ (CPSIL-19 CB, Chrompack, Middelburg, The Netherlands). Helium was the carrier gas at a flow rate of $0.55 \mathrm{ml} / \mathrm{min}$. The oven temperature was $310^{\circ} \mathrm{C}$. Samples were introduced using an all glass solid injector (Chrompack). The GC column was directly inserted into the ion source [15]. The GCMS interface was maintained at $280^{\circ} \mathrm{C}$.

\section{Evaluation of the method}

Yield of acetylation in aqueous medium DOPA $(500 \mu \mathrm{g})$ was acetylated as described. A portion (100 $\mu$ l, corresponding to $25 \mu \mathrm{g}$ of DOPA) of the reaction medium was evaporated at $60^{\circ} \mathrm{C}$ with a stream of nitrogen. The residue was treated with $50 \mu 1$ of bis(trimethylsilyl)trifluoroacetamide (BSTFA, Pierce) at room temperature for $15 \mathrm{~min}$. At these conditions pure DOPA was converted to its 3,4-O-trimethylsilyl ether, carboxy-trimethylsilyl ester derivative (DOPA-TMS 3 ). This compound eluted at $248^{\circ} \mathrm{C}$ using the current CPSIL-19 CB capillary column of which the temperature was programmed from its initial temperature of $200^{\circ} \mathrm{C}$ to a final temperature of $270^{\circ} \mathrm{C}$ at a rate of $8^{\circ} \mathrm{C} / \mathrm{min}$. One microlitre of the mixture was injected into the GCMS and analysed using electron impact MS (EIMS) on the presence of trimethylsily derivatives of native or partially acetylated DOPA.

Derivatization with PFB-Br DOPA $(25 \mu \mathrm{g})$ was passed through the entire procedure. Any remaining free acid of DOPA-triacetyl after the treatment with PFB-Br was trimethylsilylated as described above. Its absence or presence was confirmed by GC-EIMS analysis. The GC column temperature was increased from 
its initial temperature of $250^{\circ} \mathrm{C}$ to a final temperature of $320^{\circ} \mathrm{C}$ at a rate of $8^{\circ} \mathrm{C} / \mathrm{min}$.

Linearity of the procedure Standards containing DOPA ranging from $3 \mathrm{ng}$ to 50 $\mu \mathrm{g}$ were processed and subsequently dissolved and/or diluted with ethyl acetate to a final concentration of $30 \mathrm{pg} / \mu \mathrm{l}$. ECNI-MS responses (peak area/pg) of $1-\mu \mathrm{l}$ injections of these were compared.

Recovery during sample purification Recovery during sample purification was established for labelled DOPA $\left(\left[{ }^{2} \mathrm{H}_{3}\right]\right.$ DOPA $)$. First. DOPA was added to identical plasma samples which were then divided into two series. In one series labelled DOPA was added prior to purification, whereas in the other series labelled DOPA was added to the purified samples. Experiments in duplicate were carried out at levels of 85 and $11 \mathrm{ng}$ of labelled DOPA, respectively. The recovery was determined on the ratio of the relative response of labelled DOPA/DOPA, obtained in both series.

\section{Results}

\section{Methodology}

Derivatization The phenolic amino acids in this study were derivatized in aqueous media according to two earlier methods of this laboratory, providing the $N, O$-methyl formate [11] and the $N, O$-acetyl derivatives [6], respectively. PFB esters of both forms were prepared and the resulting mixed derivatives were investigated in order to select their most suitable form to sensitive GC-ECNIMS analysis. Acetyl-PFB derivatives were found to possess favorable chromatographic properties when compared to the methyl formate-PrB form. At the maximum column temperature $\left(320^{\circ} \mathrm{C}\right)$ DOPA-formate-PFB appeared in the chromatogram as a broad peak at a long retention time. The corresponding acetyl derivative eluted at the same conditions in a sharp symmetrical peak within about $4 \mathrm{~min}$, providing a more sensitive assay.

The yield of acetylation in aqueous media was investigated. Normally, these reactions were rapid and gave high yields when performed at high, constant $\mathrm{pH}$ of the medium. $[11,12,16]$. This condition was not suitable for DOPA since DOPA is unstable in alkaline solution [2]. It was found that the yield of triacetyl-DOPA increases with increasing $\mathrm{pH}$ until a plateau was reached in the $\mathrm{pH}$ range $7.58 \mathrm{~b} 18.5$. At higher $\mathrm{pH}$ values the yield decreases, in particular when addition of reagent was somewhat delayed. The amount of reagent was kept to a minimum as excess reagent will rapidly hydrolyse and resulting acetic acid will decrease the $\mathrm{pH}$. In order to keep the $\mathrm{pH}$ as constant as possible the capacity of the phosphate buffer was increased from $1 \mathrm{~mol} / 1$ [11] to $3 \mathrm{~mol} / \mathrm{l}$. Using the conditions as described (see 'Experimental') the following $\mathrm{pH}$ course was realized. The initial $\mathrm{pH}$ was 7.9 , which rapidly $(<1 \mathrm{~min}$ ) decreases to a final value of 7.6 due to hydrolysis of $30 \mu \mathrm{l}$ of acetic anhydride. The yield of triacetyl-DOPA was estimated using GCMS by 
analysing for native and partially acetylated DOPA remaining in the aqueous phase. The results indicated that under above conditions a quantitative yield was obtained.

Isolation of acetyl derivatives and esterification After acetylation, modified amino acids behave as acidic compounds. Their recovery during extraction will be determined by the $\mathrm{p} K_{\mathrm{a}}$ value of the carboxylic group. A S-shaped curve was obtained (not shown) which describes the relationship between extraction yield and the $\mathrm{pH}$ of the aqueous phase. The maximum extraction recovery was obtained at $\mathrm{pH} \leq 3.5$ ( $\mathrm{p} K_{\mathrm{a}}=2.3$ for carboxylic group of native DOPA [17]).

PFB esters of $N, O$-acetyl amino acids were prepared according to Strife and Murphy [8], slightly modified by replacing diisopropylamine by triethylamine. The yield of the ester was quantitative as judged, after trimethylsilylation, by GCMS analysis measuring any remaining free acid. Isolation of esters was performed by washing the diluted (ethyl acetate) reaction mixture with hydrochloric acid. By this treatment triethylamine and probably other impurities were removed which considerably improved the chromatography.

Purification of plasma and CSF samples During extraction of acidified samples a separation was achieved between organic acids (and neutral compounds) into the organic phase [18] and amino acids into the aqueous phase. The latter being facilitated by complete protonation of the amino group $\left(\mathrm{p} K_{\mathrm{a}}=8.7\right.$ for amino group

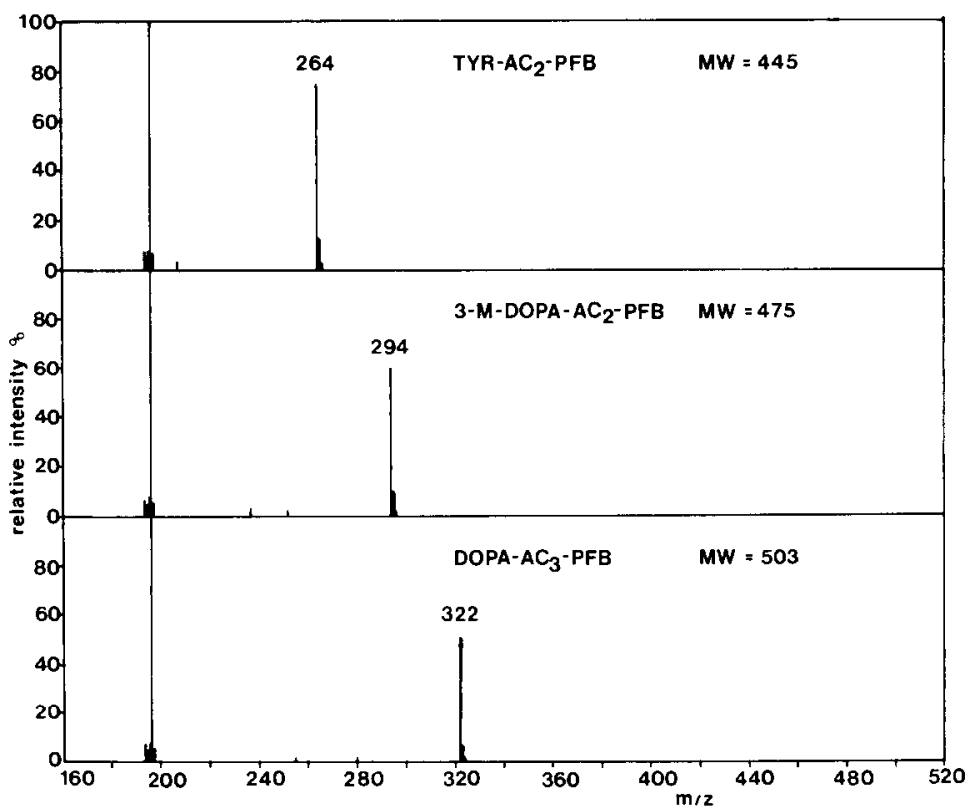

Fig. 1. Negative ion mass spectra of $N, O$-acetyl carboxypentafluorobenzyl esters of tyrosine (top), 3- $O$-methyl DOPA (middle) and DOPA (bottom). 
of DOPA [17]). The recovery of amino acids in the aqueous phase was estimated by additions of $\left[{ }^{2} \mathrm{H}_{3}\right]$ DOPA to plasma samples. Recovery was $100 \%$ and $87 \%$ at the level of 85 and $11 \mathrm{nmol} / 1$, respectively.

Linearity of the method The overall linearity of the method was estimated for standards of DOPA in the range of $3 \mathrm{ng}-50 \mu \mathrm{g}$. The response obtained from the low range sample (2533, arbitrary counts/pg) was not essentially different from that obtained from the high range sample $(2010$, ibid.) The result indicates that the method was linear over more than 4 decades.

\section{Mass spectrometry}

The electron capturing properties of the PFB group at the terminal carboxyl group gave relatively intense signals under ECNI conditions. After expulsion of the PFB group (181 daltons) from the ionized molecular species, the negative charge is delocalized by the carboxyl moiety resulting in stable carboxylate anions. ECNI mass spectra of derivatized standards (Fig. 1) of Tyr, OMD and DOPA showed abundant carboxylate anions (M-181) at $-m / z 264,294$ and 322, respectively. Molecular ions with significant intensities were not observed. The common low

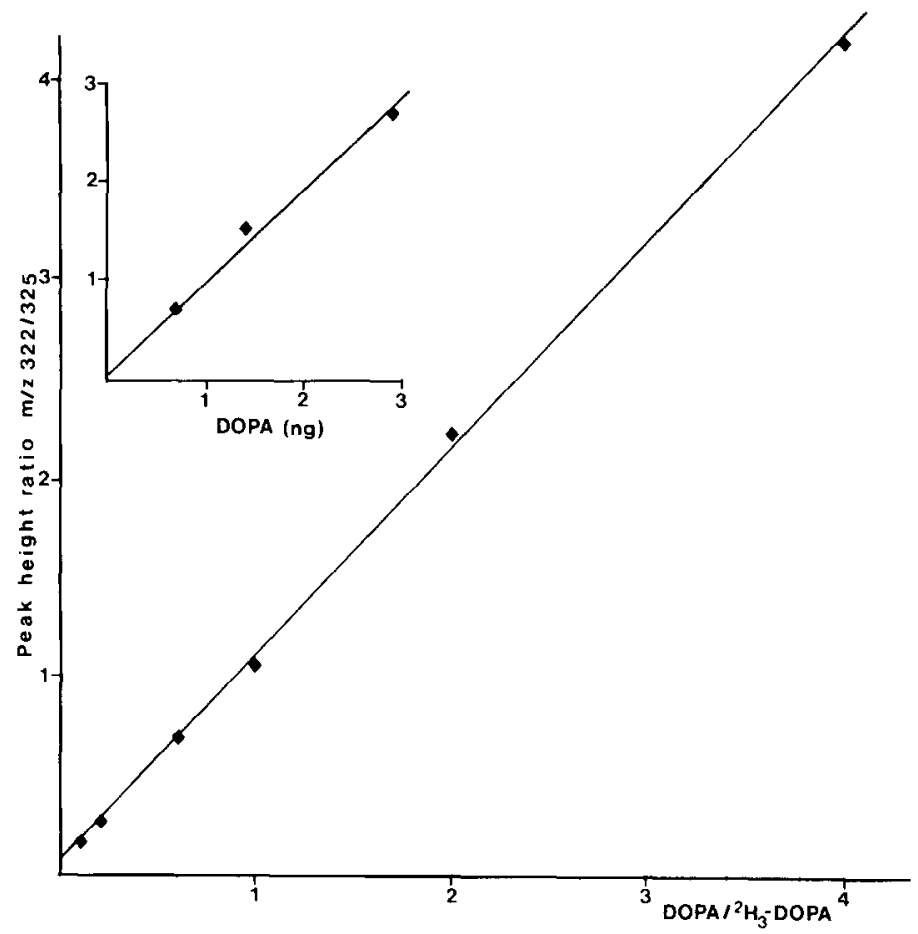

Fig. 2. Calibration curve for DOPA. Internal standard, $\left[2,5,6-{ }^{2} \mathrm{H}_{3}\right]$ DOPA (7.5 ng). Inset: $1 \mathrm{ng}$ internal standard. 
TABLE 1

DOPA and OMD $^{a}$ in normal fasting plasma and selected CSF samples obtained in this study; comparison with previous reports

\begin{tabular}{|c|c|c|c|c|c|c|}
\hline \multirow[t]{2}{*}{ Reference } & \multirow[t]{2}{*}{ Method $^{b}$} & \multicolumn{3}{|l|}{ DOPA } & \multicolumn{2}{|l|}{ OMD } \\
\hline & & Plasma & & $\mathrm{CSF}$ & Plasma & $\mathrm{CSF}$ \\
\hline This study & GC-ECNIMS & $\overline{9.0 \pm}+\overline{2.0}$ & $(n=11)$ & $3.5 \pm 0.9(n=9)$ & $99.1^{\mathrm{c}}$ & $15.3^{4}$ \\
\hline 3 & HPLC-EC & $32(10-50)$ & $(n=20)$ & - & - & - \\
\hline 4 & REA & $6.1(6.6-15)$ & $(n=4)$ & - & - & - \\
\hline 31 & HPLC-EC & $12.7 \pm 1.9$ & $(n=5)$ & $(n=1)$ & - & - \\
\hline 32 & HPLC-EC & $4.3 \pm 1.9$ & $(n=31)$ & - & - & - \\
\hline 33 & HPLC-EC & 10.6 & $(n=9)$ & - & - & - \\
\hline 34 & REA & $7.3 \pm 0.1$ & $(n=43)$ & - & - & - \\
\hline 35 & HPLC-EC & $3.6 \pm 1.3$ & $(n=4)$ & - & $108.8 \pm 26(n=5)$ & - \\
\hline
\end{tabular}

a $\mathrm{nmol} / \mathrm{l}$; mean $\pm \mathrm{SD}$ or range ( $n=$ number of subjects).

${ }^{b}$ HPLC-EC, high performance liquid chromatography-electrochemical detection;

$R E A$, radioenzymatic assay.

" Pooled plasma samples $(n=24)$.

d Pooled CSF samples $(n=12)$.

mass fragment ion at $-m / z 196\left(\left[\mathrm{CHOC}_{6} \mathrm{~F}_{5}\right]^{-}\right.$[7]) has no diagnostic value, as it has been observed previously for other PFB esters [6-8].

The limit of detection (signal-to-noise ratio $>5$ ) was about $0.1-0.2 \mathrm{pg}$ on column using selected ion monitoring of the carboxylate anions.

\section{Quantitative results}

Figure 2 shows a calibration curve for DOPA. Similar curves were routinely obtained for OMD. Imprecision of the method (within a batch) was determined by analyzing DOPA in six aliquots of a plasma pool. The mean concentration $(9.4$ nmol/1) was determined using a relative standard deviation (RSD) of $5 \%$. Analytical

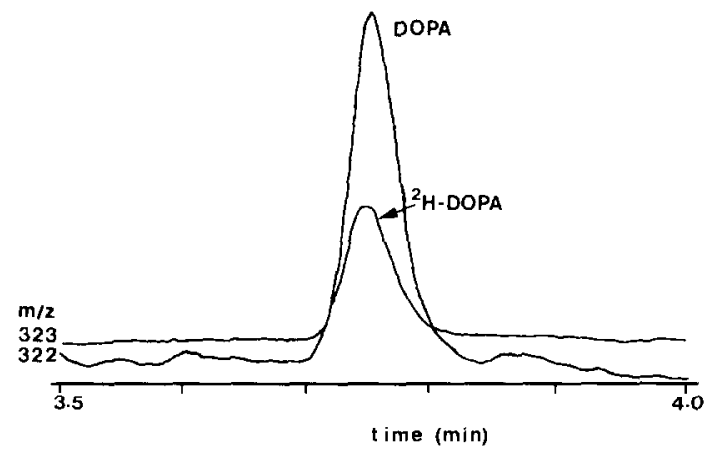

Fig. 3. GC-ECNIMS analysis of DOPA $(\mathrm{m} / z 322)$ and 5-[ $\left.{ }^{2} \mathrm{H}\right]$ DOPA $(m / z 323)$ in a plasma sample of a individual orally loaded with $3.5-\left[{ }^{2} \mathrm{H}_{2}\right]$ tyrosine. Sample drawn $1 \mathrm{~h}$ after the load. GC oven temperature $320^{\circ} \mathrm{C}$. 


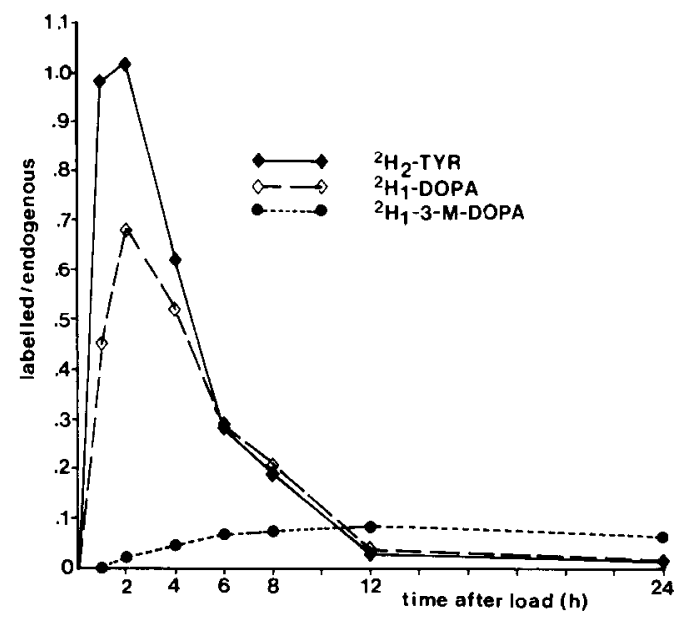

Fig. 4. Relative plasma content of labelled tyrosine, DOPA and 3-O-methyl DOPA in a control subject orally loaded with $150 \mathrm{mg} / \mathrm{kg}$ of $3,5-\left[{ }^{2} \mathrm{H}_{2}\right]$ tyrosine.

recovery was determined using plasma to which $108 \mathrm{nmol} / 1$ of DOPA was added. A concentration of $108.3 \pm 4 \mathrm{nmol} / \mathrm{l}$ was recovered, being $100.2 \pm 3.7 \%$ (mean $\pm \mathrm{RSD}$, $n=4)$. The method was applied to the determination of DOPA and OMD in fasting plasma of apparently healthy adults and in selected CSF samples from hospitalized adults, who were not expected to have abnormal DOPA and/or OMD levels. The assay of DOPA was performed in individual samples, whereas levels of OMD in plasma and CSF were determined in pools of plasma samples and CSF samples, respectively. The results are shown in Table $\mathrm{I}$.

Finally, the method was applied to the measurement of $5-\left[{ }^{2} \mathrm{H}\right] \mathrm{DOPA}$ and $5-\left[{ }^{2} \mathrm{H}\right] \mathrm{OMD}$ appearing in plasma of a healthy control individual who had been orally loaded with $\mathrm{L}-3,5-\left[{ }^{2} \mathrm{H}_{2}\right]$ tyrosine $(150 \mathrm{mg} / \mathrm{kg}$ body wt). Figure 3 shows an example of the simultaneous analysis of DOPA and its $\left[5-{ }^{2} \mathrm{H}\right]$ isomer in a $1-\mathrm{ml}$ plasma sample, which was drawn $1 \mathrm{~h}$ after the load. Figure 4 shows time courses of the relative content (labelled/non-labelled) of deuterated isomers of Tyr, DOPA and OMD in plasma for a period of $24 \mathrm{~h}$ after the load. Accuracy and precision for the determination of the ratio $\left[{ }^{2} \mathrm{H}\right] \mathrm{DOPA} / \mathrm{DOPA}$ was established by analyzing the relative abundance of the naturally occurring isotope $(\mathrm{m} / \mathrm{z}-323)$ of the [M-PFB]ion $(m / z-322)$ of plasma DOPA. The intensity ratio of $323 / 322$ was determined in normal plasma as $0.181 \pm 0.01$ (mean $\pm \mathrm{SD}, n=4$ ), being $106 \pm 5.5 \%$ of its calculated [19] theoretical value of 0.175 .

\section{Discussion}

The aim of this study was to develop a convenient and reliable work-up procedure for DOPA and other phenolic amino acids from biological samples that exploit the sensitivity of the ECNI mass spectrometry. In vivo studies which makes 
use of deuterium labelled amino acids [20-25] need the availability of a mass spectrometric method. The detection of DOPA and traces of its $\left[{ }^{2} \mathrm{H}\right]$ isomer in plasma or CSF needs a highly sensitive MS method. Operating the mass spectrometer at a low resolving power (eg $R=1000$ ), the naturally occurring isotope peak of DOPA will coincide with the peak of $\left[{ }^{2} \mathrm{H}\right]$ DOPA. The height of the resultant baseline amounts 17.5 (see 'Results') of the intensity of the DOPA signal. For normal plasma and CSF this base line level corresponds to about 1.5 and 0.5 nmol/1, respectively (see Table I for normal DOPA levels). The required sensitivity of the method would be such that accurate differential analysis of borderline $\left[{ }^{2} \mathrm{H}\right]$ DOPA levels in these fluids will be attainable.

For the devise of the present method we made benefit of recently developed methodology for derivatization of amines and phenols in aqueous media [11-13,26] and for the preparation of PFB esters $[6,8,27,28]$. Procedures for the latter derivatization have shown to be valid in some applications [6-8,29].

Goal-directed use of aqueous derivatization techniques allow that purification of biological samples as well as isolation of amino acids were readily accomplished by means of simple organic solvent extraction. Before acylation, extraction allows the complete elimination of neutral and acidic compounds [18] and the elimination of proteins to a great extent. Thereafter, modified amino acids behave as ordinary acidic compounds which are easily recovered during extraction. Moreover, simultaneous acylation of phenolic hydroxyl groups will improve the extraction efficacy. It was shown [30] that hydroxyl groups at position 3 and 4 of dihydroxybenzoic acid markedly reduce the extraction yield. These functions are able to undergo hydrogen bonding which stabilize the analyte in the aqueous medium. After acetylation this ability will be lossed.

Recently, Ahnfelt and Hartvig [10] described a comparable method for aminobutyric acids. After reaction of the amino function with trichloroethyl formate in aqueous medium, methyl esters were prepared using an extractive alkylation technique. This elegant method for esterification was unsuccessful when applied to prepare PFB esters of $\mathrm{N}, \mathrm{O}$-acetylated amino acids because hydrolysis of $O$-acetyl groups occurred during extractive alkylation.

The concentrations for DOPA and OMD found in normal plasma (Table I) are in good agreement with previous results [4,31-35]. Reports on control levels of DOPA and OMD in CSF are scanty. A value reported for DOPA in CSF from a single individual [31], was within the range obtained in this study (Table I).

Until now, not much attention has been paid to the biochemistry of OMD. Normally, it is excreted in urine in relatively small amounts when compared to primary dopamine metabolites like homovanillic acid (HVA) and dihydroxyphenylacetic acid (DOPAC). The opposite was found for plasma, in which the concentration of OMD was about 1.5 times that of HVA and 5-6 times that of DOPAC (cf reference [6] for plasma levels of HVA and DOPAC), indicating that it will be cleared at a low rate from the blood. In patients on DOPA therapy (eg in Parkinsons disease), it was shown that 3-O-methylation became a prominent metabolic pathway of administered DOPA [36]. This causes high OMD plasma levels [36-39], especially when the therapy regime includes the concomitant use of a 
peripheral acting amino acid decarboxylase inhibitor. Because OMD is able to pass the blood brain barrier [39], high plasma levels will cause increased levels in brain tissue and in CSF [40]. Its function or action in brain is not clear if it has any function et al. However, OMD has been associated with central side effects of DOPA therapy [41]. The present method would be useful for further in vivo kinetic studies of DOPA and associated compounds, their metabolism and distribution over various body compartments. We have performed preliminary in vivo experiments by oral loading of a normal individual with $\mathrm{L}-\left[3,5-{ }^{2} \mathrm{H}_{2}\right]$ tyrosine. Earlier, Sjöquist [21] used $2,6, \alpha-\left[{ }^{2} \mathrm{H}_{3}\right]$ tyrosine to determine catecholamine turnover. For the latter compound it was shown that it does not cause isotope effects in hydroxylation of tyrosine at the 3 position. Guroff and Daly [42] showed that there was no isotope effect in hydroxylation in the 4 position of $4-\left[{ }^{2} \mathrm{H}\right]$ phenylalanine. Whether tyrosine hydroxylase will be affected by the presence of a deuterium atom at the 3 position is not known. Additionally, it seems to be unlikely that the deuterium atom in position 5 will exert an isotope effect in further DOPA metabolism. Consequently, labelled metabolites of DOPA will reflect the in vivo kinetics of the endogenous products.

Time courses for $\left[{ }^{2} \mathrm{H}_{2}\right]$ Tyr and $\left[{ }^{2} \mathrm{H}\right]$ DOPA (Fig. 4) measured in plasma of a healthy individual who was given an oral load of the labelled tyrosine, indicate that the biosynthesis of DOPA proceeds rapidly in man. The estimated plasma DOPA biological half-life $\left(t_{1 / 2}\right)$ was about 15-20 min, which was considerably shorter than could be infered from disappearance time courses for plasma DOPA reported by Fahn [43], which indicate a plasma $t_{1 / 2}$ of orally administered DOPA of about $1 \mathrm{~h}$. The half-life of OMD was about $12 \mathrm{~h}$. Calculation of OMD half-life was performed using the urine time course of $\left[{ }^{2} \mathrm{H}\right] \mathrm{OMD}$ of the same subject (data not shown). Data from urine samples were available during the first $48 \mathrm{~h}$ after the load, whereas plasma samples were available during only the first $24 \mathrm{~h}$. Calculation of such a long half-life needs data over a time period of at least $48 \mathrm{~h}$. The long half-life of OMD confirms the above noted low rate of DOPA metabolism via the $O$-methylation pathway at steady-state conditions.

In summary, the results presented in this paper demonstrate the utility of the method for quantitative measurements and kinetic studies on DOPA as the precursor for catecholamines in man. This method together with earlier developed mass spectrometric methods for catecholamines [11] and their acidic metabolites [6] may open new fields in neurochemical studies on DOPA and its metabolites in diseases such as Parkinsonism and torsion dystonias.

\section{References}

1 Nagatsu, T, Levitt $M$, Udenfriend $S$. Tyrosine hydroxylase, the initial step in norcpincphrine biosynthesis. J Biol Chem 1964;239:2910-2917.

2 Bremer HJ, Duran M, Kamerling JP, Przyrembel H, Wadman SK, eds. Disturbances of amino acid metabolisme: clinical chemistry and diagnosis, Baltimore/Munich: Urban and Schwarzenberg, $1981 ; 64$.

3 Hansson C, Eldholm LE, Agrup G, Rorsman H, Rosengren AM, Rosengren R. The quantitative determination of 5-S-cysteinyldopa and DOPA in normal serum and in serum from patients with malignant melanoma by means of high-pressure liquid chromatography. Clin Chim Acta 1978;88:419-427. 
4 Desmassieux S. Corneille L, Lachanca S, Carriere S. Determination of free and conjugated catecholamines and L-3.4-dihydroxyphenylalanine in plasma and urine: evidence for a catechol- $O$ methyltransferase inhibitor in uraemia. Clin Chim Acta 1981;115:377-391.

5 Hunt DF, Crow FW. Electron capture negative ion chemical ionization mass spectrometry. Ann Chem 1978;50:1781-1784.

6 De Jong APJM, Kok RM, Cramers CA, Wadman SK. Determination of acidic catecholamine metabolites in plasma and cerebrospinal fluid using gas chromatography-negative ion mass spectrometry. J Chromatogr 1986;382:19-30.

7 Waddell KA, Blair IA, Welby J. Combined capillary column gas chromatography negative ion chemical ionization mass spectrometry of prostanoids. Biom Mass Spectrom 1983;10:83-88.

8 Strife RJ. Murphy RC. Preparation of pentafluorobenzyl esters of arachidonic acid lipoxygenase metabolites. Analysis by gas chromatography and negative-ion chemical ionization mass spectrometry. J Chromatogr 1984;305:3-12.

9 Labadarios D, Moodie IM, Shephard GS. Gas chromatographic analysis of amino acids in physiological fluids: a critique. J Chromatogr 1984;310:223-231.

10 Ahnfelt N-O. Hartvig P. Two-step derivatization of aminobutyric acids and determination by electron capture gas chromatography. Acta Pharm Suec 1982:19:367-380.

11 De Jong APJM, Cramers CA. Derivatization of catecholamines in aqueous solution for quantitative analysis in biological fluids. J Chromatogr 1983;276:267-278.

12 Takahashi S, Godse DD, Warsh JJ. Stancer HC. A gas chromatographic-mass spectrometric (GC-MS) assay for 3-methoxy-4-hydroxyphenethyleneglycol and vanylmandelic acid in human serum. Clin Chim Acta 1977;81:183-192.

13 Gyllenhaal O, Johansson L, Vessman J. Gas chromatography of epinephrine and norepinephrine after derivatization with chloroformates in aqueous media. J Chromatogr 1980;190:347-357.

14 Muskiet FAJ, Jeuring HJ, Thomasson CG, Van der Meulen J. Wolthers BG, Deuteration of catecholamines, catecholamine metabolites and tryptophan metabolites. J Labelled Compounds Radiopharmacol 1978;14:497-505.

15 Kok RM, De Jong APJM, Van Groeningen CJ, Peeters GJ, Lankelma J. Highly sensitive determination of 5 -fluorouracil in human plasma by capillary gas chromatography and negative ion chemical ionization mass spectrometry. J Chromatogr 1985; 343:59-66.

16 Markey SP. Colburn RW, Johannessen JN. Efficient extraction and mass spectrometric assay of serotonin in biological fluids. Biomed Mass Spectromet 1981;8:301-304.

17 Gorron IF, Jameson RF. Complexes of double chelating ligands. I Proton and copper(II) complexes of L- $\beta$-(3,4-dihydroxyphenyl)alanine (DOPA). J Chem Soc A 1968;11:2615-2618.

18 Muskiet FAJ, Fremouw-Ottevangers DC, Wolthers BG, De Vries JA. Gas-chromatographic profiling of urinary acidic and alcoholic catecholamine metabolites. Clin Chem 1977;23:863-867.

19 Beynon JH, Saunders RA, Williams AE. The mass spectra of organic molecules. Amsterdam: Elsevier, 1968;476-477.

20 Clarke JTR, Bier DM. The conversion of phenylalanine to tyrosine in man. Direct measurement by continuous intravenous tracer infusion of $\mathrm{L}-\left[\mathrm{ring}^{2}{ }^{2} \mathrm{H} 5\right]$ phenylalanine and $\mathrm{L}-\left[1-{ }^{13} \mathrm{C}\right]$ tyrosine in the postabsorptive state. Metabolism 1982;31:999-1005.

21 Sjoquist B. Analysis of tyrosine and deuterium labelled tyrosine in tissues and body fluids. Biomed Mass Spectromet 1979:6:392-395.

22 Lehmann WD, Heinrich HC. Oral versus intravenous L-phenylalanine loading compared by simultaneous application of $\mathrm{L}-\left[{ }^{2} \mathrm{H} 5\right]$ and $\mathrm{L}-\left[{ }^{15} \mathrm{~N}\right]$ phenylalanine. Clin Chim Acta 1985:147:261-266.

23 Faull KF, Gan I, Halpern B, Hammond J, Cotton SlmRGH, Danks DM. Metabolic studies on two patients with nonhepatic tyrosinemia using deuterated tyrosine loads. Pediatric Res 1977:11:631-637.

24 Freed CR, Murphy RC. Mass spectrometric measurement of catecholamine turnover in rat hypothalamus after long-term L-DOPA infusion. J. Pharmacol Exp Therapy 1978:205:702-709.

25 Edwards DJ. Rizk M. Conversion of 3,4-dihydroxyphenylalanine and deuterated 3,4-dihydroxyphenylalanine to alcoholic metabolites of catecholamines in rat brain. J Neurochem 1981:36:1641-1647.

26 Ahnfelt N-O. Hartvig P. Gas chromatographic analysis of primary and secondary amines after derivatization with chloroformates in buffered aqueous solution. Acta Pharm Suec 1980;17:307.

27 Blair IA, Barrow SE, Waddell KA, Lewis PJ, Dollery CT. Prostacyclin is not a circulating hormone in man. Prostaglandins 1982;23:579-589. 
28 Min BH, Pao J, Garland WA, De Silva JAF, Parsonnet M. Determination of an antisecretory trimethyl prostaglandine $E_{2}$ analog in human plasma by combined capillary column gas chromatography-negative chemical ionization mass spectrometry. J Chromatogr 1980;183:411-419.

29 Roberts LJ, Pentafluorobenzyl derivate of histamine for determination by gas chromatography-negative ion chemical ionization mass spectrometry. J Chromatogr 1984;287:155-160.

30 Puttermans M, Dryon L, Massart DL. Extraction of organic acids by ion-pair formation with tri-n-octylamine. Ann Chim Acta 1984;161:221-229.

31 Shum A, Van Loon GR, Sole MJ. Measurement of L-dihydroxyphenylalanine in plasma and other biological fluids by high pressure liquid chromatography with electrochemical detection. Life Sci 1982:31:1541-1545.

32 Ito S, Kato T, Maruta K, Fujita K. Determination of DOPA, dopamine and 5-S-cisteinyl-DOPA in plasma, urine and tissue samples by high-performance liquid chromatography with electrochemical detection. J Chromatogr 1984;311:154-159.

33 Goldstein DS, Stull R, Zimlichman R. Levinson PD, Smith H, Keiser HR. Simultaneous measurement of DOPA, DOPAC and catecholamines in plasma by liquid chromatography with electrochemical detection. Clin Chem 1984;30:815-816.

34 Johnson GA, Gren JM. Kupiekci R. Radioenzymatic assay of DOPA (3,4-dihydroxyphenylalanine). Clin Chem 1978;24:1927-1930.

35 Itsimitsu T, Hirose S. Simultancous assay of 3,4-dihyroxyphenylalanine, catecholamines and $O$-methylated metabolites in human plasma using high-performance liquid chromatography. $J$ Chromatogr 1985:337:239-248.

36 Rivera-Calimlim L, Tadon D, Anderson F, Joynt R. The clinical picture and plasma levodopa metabolite profile of Parkinsonian nonresponders. Arch Neurol 1977;34:228-232.

37 Muskiet FAJ, Jeuring HJ, Teelken AW, Wolthers BG, Lakke JPWF. Identification and quantification of 3-methoxy-4-hydroxyphenyllactic acid (VLA) in cerebrospinal fluid and 3-methoxy-4-hydroxyphenylpyruvic acid (VPA) in the urine of Parkinsonian patients treated with L-dopa. J Neurochem 1978;31:1283-1288.

38 Mizuno Y. Simple gas chromatographic analysis of plasma dopa and dopamine. Clin Chim Acta 1977:74:11-19.

39 Rivera-Calimlim L. Absorption, metabolism and distribution of ${ }^{14} \mathrm{C}$-O-methyldopa and ${ }^{14} \mathrm{C}$ - $\mathrm{L}$-dopa after oral administration to rats. Br J Pharmacol 1974;50:259-263.

40 Sharpless NS, McCann DS. Dopa and 3-O-methyldopa in cerebrospinal fluid of Parkinsonism patients during treatment with oral L-dopa. Clin Chim Acta 1971;31:155-169.

41 Marsden CD, Parkes JD, Rees JE. Progress in the treatment of Parkinsonism. In: Calne DB, ed. Advances in neurology, Vol. 3. New York: Raven Press, 1973;79-96.

42 Guroff G. Daly J Quantitative studies on the hydroxylation-induced migration of deuterium and tritium during phenylalanine hydroxylation. Arch Biochem Biophys 1967;122: 212-217.

43 Fahn S. 'On-Off' phenomenon with levodopa therapy in Parkinsonism. Neurology 1974;24:431-441. 